\title{
Effect of three drying methods on the physicochemical composition of three varieties of onion (Allium cepa $\mathrm{L}$ ).
}

\author{
Abdou Bouba Armand ${ }^{1 *}$, Joel Scher ${ }^{1}$, Aboubakar ${ }^{2}$, Goudoum Augustin $^{3}$, Ponka Roger ${ }^{3}$, Didier Montet ${ }^{4}$, Mbofung \\ Carl Moses ${ }^{5}$ \\ ${ }^{1}$ LIBio, University of Lorraine, Laboratory of Biomolecule Engineering, 2 avenue de la Foret de Haye, B.P. 172, 54505 \\ Vandoeuvre-les-Nancy, France \\ ${ }^{2}$ Department of Biological Science, Faculty of Science, University of Maroua, PO Box 814 Maroua, Cameroon \\ ${ }^{3}$ Department of Agriculture, Livestock and By-products, ISS, University of Maroua, PO Box 46 Maroua, Cameroon \\ ${ }^{4}$ CIRAD, UMR 95 Qualisud, TA B95/16, 34398 Montpellier cedex 5, France \\ ${ }^{5}$ Department of Food Science and Nutrition, ENSAI, University of Ngaoundere, PO Box 686 Ngaoundere, Cameroo
}

\begin{abstract}
The effect of solar and electric drying on physicochemical composition of onion (Allium cepa L) has been studied to reduce the post-harvest losses of onion bulbs. The physicochemical and biochemical composition of three varieties of onion (White of galmi, Violet of galmi and Goudami) were also investigated using the Fourier transform infrared (FT-IR) spectroscopy $(4000-400 \mathrm{~cm}-$ 1) and scanning electron microscopy (SEM). Protein, sugar, lipid, moisture, ash, vitamin C, and color parameters were assayed on fresh and dried onion powders. The results showed that water was the main constituent of the fresh onion bulbs $(87 \%)$. They were also rich in available sugars ranging from $19 \mathrm{~g}$ to $59 \mathrm{~g} / 100 \mathrm{~g}$ and proteins $4 \mathrm{~g}$ to $11 \mathrm{~g} / 100 \mathrm{~g}$ of dry matter (DM). Moreover, $\mathrm{Ca}, \mathrm{K}, \mathrm{P}$, and $\mathrm{Mg}$ were found to be the major minerals of the onion powders. In general, the drying process influenced significantly $(\mathrm{P}<0.05)$ all the parameters, especially vitamin $\mathrm{C}$ that decreased considerably during the process with $90.55 \%, 78.71 \%$ and $72.50 \%$ for White of galmi, Goudami and Violet of galmi respectively. The FT-IR spectra showed major peaks were at the wavelength of $1024 \mathrm{~cm}-1$. This could be due to vibrational frequency of $\mathrm{ACH} 2 \mathrm{OH}$ groups of carbohydrates for the three studied varieties and for the two types of drying. Finally, a nonsignificant correlation was observed between drying methods and varieties of onion powders.
\end{abstract}

Keywords: Allium cepa L, Dehydration, Post-harvest, FT-IR, Physicochemical, SEM.

\section{Introduction}

Vegetables are seasonal and perishable commodities which have a very limited availability period due to the lack of post-harvest technology in this food chain. Indeed, post-harvest losses have been the object of much debate all geared at reducing these losses modes to increase the consumption of edible foods. Food losses have an important role at production, postharvest and processing stages in the food supply chains [1].

Onion (Allium cepa $\mathrm{L}$ ) is considered as one of the most widely consumed vegetables and the oldest cultivated crops in almost all countries of the world [2]. The annually consumption per capita is about $5.5 \mathrm{~kg}$ of onions worldwide [3]. After tomatoes, this plant is the second most produced horticultural vegetable with a worldwide production of about 64.5 million tons on 3.45 million ha area [4]. Many studies reported its preventive and curative effects for eye inflammation, respiratory problem, fight against infections due to its sulfur compounds and its anti atherogenic effects [5]. Furthermore, studies on the physicochemical composition of onion exhibited that; its principal component was carbohydrates along with proteins, some vitamins, minerals, and phenolic compounds [6,7]. Preliminary investigations revealed that the cultivation of onions is of great importance among the vegetables in the national strategy of fight against poverty in Cameroon. In certain production zones of the country, onion is presented as the first product of speculation in between vegetables and the second in the commercial products after cotton [8] and its annual production goes up to 95,000 T per year. This vegetable has an important place in the daily diet of the local population in Cameroon and it is used as an ingredient in about $80 \%$ of their daily meals. In spite of its high rate of production, Cameroon does not manage to ensure its annual needs for this vegetable consumption because of the cumulated factors of seasonal variation of production and their high moisture content. To add, the absence of suitable infrastructures decreases onion preservation. All these factors are responsible of $40 \%$ annual onion loss of the total production in Cameroon [9].

The post-harvest losses are then very costly for the producers who lose substantial benefit. Consequently, Cameroon is forced to import thousand tons of onions coming from Holland, Nigeria and Chad, to cover up the annual needs. The loss of quality during conservation remains the largest constraint of the production and has the greatest incidence on the price fluctuation on the national market (600-700\%).

For these reasons, the combined use of new technology and modern preservative practices is necessary to reduce the postharvest losses. Therefore, the transformation of onion into powder by adequate drying methods could be a way for the surplus management of the production during low availability or non-production periods [9]. 
For this purpose, dehydration of plants can be performed using different methods: Natural drying (drying in the shade) and hot air drying are still most widely used methods due to their lower cost. It is intensively applied in subtropical regions where sunlight is present all over the year. Reduction of postharvest losses represents a large business opportunity but this field of research and development received a limited attention in Cameroon [10].

In the same way, drying is an effective method that increases the shelf life of the final product by slowing the growth of microorganisms and preventing certain biochemical reactions that may alter the organoleptic characteristics [11] and it is one of the oldest methods widely used for fruit and vegetable preservation [12]. Although, the influence of hot air drying on food quality is well known, the understanding of processes caused by dewatering that adversely affect material properties is limited. The major challenge during drying of food materials is to reduce the moisture content of the material to the desired level without substantial loss of flavor, taste, color and nutrients.

The present work aims at study the relation between solar and electric dehydration and the physico-chemical composition of three onion (Allium cepa L) varieties (Goudami, White of galmi, and Violet of galmi) that could be beneficial for the improvement of onion storage conditions in Cameroon.

\section{Material and Methods}

\section{Onion samples and dehydration}

The varieties of onions Goudami, White of galmi and Violet of galmi were obtained from Meskine-Maroua farm in Cameroon. Once the bulbs were selected, damaged onions and remaining such as leaves and soil were removed. Cleaning operation was done manually using a stainless steel knife. The bulbs were cut into thin strips of $0.25 \mathrm{~cm}$ to $0.3 \mathrm{~cm}$ thick. Two types of dehydration were used: solar dehydration and electric dehydration. Solar dehydration was carried out at $34^{\circ} \mathrm{C}$ average for 6 days on wooden racks manufactured by ENSAI of University of Ngaoundere. Drying by ventilation was done with an electric turning dryer (Riviera and Bar) at room temperature $\left(25^{\circ} \mathrm{C}\right)$ for 4 days. After dehydration, dry onions were milled using an electric grinder (Culatti, Polymix, France) through a $500 \mu \mathrm{m}$ sieve. The obtained powders were fresh stored in polyethylene bags at $4^{\circ} \mathrm{C}$ until analysis.

\section{Proximate chemical analysis}

Crude protein, ash and moisture content of fresh and powdered onion were carried out according to standards [13]. Flour samples were acid-hydrolyzed, and the reducing sugar known as available carbohydrates was determined by the dinitrosalicylic acid (DNS) method as described by Fisher and Stein [14]. For lipid content, the cold extraction method was used [15]. Following this procedure, $50 \mathrm{~g}$ of onion powder samples were introduced in volumetric flasks containing $300 \mathrm{~mL}$ of a mixture of chloroform/methanol $(200 \mathrm{~mL} / 100 \mathrm{~mL})$ and mixed for $20 \mathrm{~min}$. The mixture was filtered under $\mathrm{N}_{2}$ and the residue re-extracted in $200 \mathrm{~mL}$ of the same solvent and filtered. The extracts were then mixed and allowed to separate after the addition of $0.2 \mathrm{~mL}$ of $\mathrm{NaCl}$ solution at $0.7 \mathrm{~g} / 100 \mathrm{~mL}$. Lipids were recovered by rotary evaporation at $50^{\circ} \mathrm{C}$ under liquid Nitrogen. The extracted oil was weighed and the difference in weight expressed as percentage oil content. Vitamin $\mathrm{C}$ was analyzed by titration as previously described with some modifications [16]. $2 \mathrm{~g}$ of sample was dissolved in a $25 \mathrm{~mL}$ volumetric flask containing $20 \mathrm{~mL}$ of distilled water. After mixing for $10 \mathrm{~min}$, the mixture was titrated with 2,6 di-chlorophenol indophenol solution (5 $\mathrm{mg} / \mathrm{mL})$. A standard sample of ascorbic acid $(0.1 \mathrm{mg} / 100 \mathrm{~mL})$ was used as reference and the results expressed in $\mathrm{mg}$ vitamin $\mathrm{C} / 100 \mathrm{~g}$ DM.

\section{Determination of mineral contents}

Onion powders $(2.5 \mathrm{~g})$ were weighed out into beakers and ashed at $550^{\circ} \mathrm{C}$ overnight. The resulting white-ash residue was dissolved in $4 \mathrm{~mL} \mathrm{HCL} \mathrm{(99 \% ),} \mathrm{filtered} \mathrm{and} \mathrm{adjusted} \mathrm{to} 10 \mathrm{~mL}$ with distilled water. The resulting extract was analyzed for their content of specific major minerals. Iron $(\mathrm{Fe})$ was determined with an ICP-OES [17], ICP-OES Varian-Vista, RF Power 0.7$1.5 \mathrm{kw}$ (1.2-1.3 kw for Axial), Plazma gas flow rate (Ar) 10.5$15 \mathrm{~L} / \mathrm{min}$ (radial), $15 \mathrm{~L} / \mathrm{min}$ (axial), auxiliary gas flow rate (Ar) 1.5 L/min, Viewing height 5-12 mm, copy and reading time 1-5 $\sec (\max 60 \mathrm{sec})$, copy time $3 \mathrm{sec}(\max 100 \mathrm{~s})$. Na, K, Mn, $\mathrm{Mg}, \mathrm{Ca}, \mathrm{Zn}$ and $\mathrm{Cu}$ were determined by atomic absorption spectrophotometer (Pharmacia biotech Ultraspec 4000) [18].

\section{pH and color measurement}

The $\mathrm{pH}$ was assessed by different water suspensions of powders. $1 \mathrm{~g}$ sample was dissolved in $50 \mathrm{~mL}$ of deionised water and homogenized for $10 \mathrm{~min}$. The $\mathrm{pH}$ of the solution was then read with a pH-meter (Checker pH Tester, Hanna Instruments). Color measurements of flour samples were carried out using a portable tintometer (Lovibond RT Color Measurement Kit V2.28) with a $10^{\circ}$ observer window and a D-65 light source. The color values generated by the equipment were expressed as L-(whiteness or darkness), a-(redness/greenness) and b-(blueness/yellowness) [19].

\section{Infra-red measurements}

Tensor 27 midFT-IR spectrometer(Brüker, Karlsruhe, Germany) with deuterated triglycine sulfate (DTGS) detector was used. A ZnSe ATR sampling accessory from spectra tech (Shelton, CT) was used for total attenuated reflection measurements. The diaphragm was set to $6 \mathrm{~mm}$ and the scanning rate to $10 \mathrm{KHz}$. In addition, 160 scans were used for both reference and sample over the frequency range of $4000-400 \mathrm{~cm}^{-1}$ at a resolution of $4 \mathrm{~cm}^{-1} .0 .02 \mathrm{~g}$ of sample was poured onto the attenuated total reflectance (ATR) ZnSe crystal. After each operation, the crystal was thoroughly cleaned up with ethanol, washed in water and then dried under nitrogen gas.

\section{Scanning electron microscopy (SEM)}

Powders analyzed are set on a double-sided tape mounted to a support. A layer of carbon $10 \mathrm{~nm}$ followed by a mixture gold / palladium is deposited on the powder particle surfaces to render them conductive. Microscopic observation of the powders is carried out under high vacuum (about 10-5 torr) by backscatter of secondary electrons by means of a scanning electron microscope Hitachi S2500, (Japan) operating at an acceleration of $17 \mathrm{KV}$. 


\section{Statistical analysis}

All the chemical analyses were done in triplicate. Obtained results were expressed as means \pm standard deviation (SD) and also subjected to one way analysis of variance and Duncan multiple test range when there was a significant $(\mathrm{p}<0.05)$ difference using [20] statistical software. Principal component analysis was performed using the statistical package, [21] to group and classify the onions according to their physicochemical composition. The infrared spectroscopy spectrums were made by opus software version Brüker optic GmbH 1997 2002.

\section{Results and Discussion}

\section{Physico-chemical composition}

Table 1 represents the results of the physiochemical characteristics except minerals carried out on some onion bulb varieties depending on to the type of dehydration. Moisture contents of the three varieties of onion corresponding to their mode of drying were observed. Average moisture content of the fresh bulbs was high ( $87 \mathrm{~g} / 100 \mathrm{~g}$ of DM) for all the varieties. The same observations were made by Ekholm et al. [22]. On three onion varieties of Finland with moisture contents which oscillated between $85.5 \mathrm{~g} / 100 \mathrm{~g}$ and $87.3 \mathrm{~g} / 100 \mathrm{~g}$ DM in the same vein of study [23]. Abhayawick et al. found almost similar moisture contents: $83 \mathrm{~g} / 100 \mathrm{~g}, 88 \mathrm{~g} / 100 \mathrm{~g}$ and $92 \mathrm{~g} / 100 \mathrm{~g}$ DM respectively for onion bulbs varieties "Niz", "Spirit" and "Sweet vidalia" cultivated in France. Nevertheless, moisture seems to justify their very strong spoilage susceptibility due to its role in solubilzation and acting as a good medium for the development of microbes. Therefore, needs were to preserve onions by dehydration for a better conservation. In addition, data also indicated that drying considerably reduced the ratio of moisture (at least 90\%) whatever the mode of treatment. However, $\mathrm{pH}$ values varied significantly $(\mathrm{p}<0.05)$ for different varieties and dehydration type. Results were 6.24 (BGF) to 6.78 (GS). This low acidity observed in these bulbs could be a limit for the conservation because acidification is well established as a mechanism of food preservation [6].

Similarly, color which constitutes a qualitative factor for the acceptability of onions by consumers was determinate by the factors $\mathrm{L}^{*}, \mathrm{a}^{*}$ and $\mathrm{b}^{*}$. It was observed that the variety and dehydration techniques influence significantly $(p<0.05)$, the parameter $\mathrm{L}^{*}, \mathrm{a}^{*}$ and $\mathrm{b}^{*}$ of the color. The coordinate $\mathrm{L}$ of the varieties characterizes the white $(\mathrm{L}=100)$ to black $(\mathrm{L}=0)$ color in the chromatic space. The greatest value of $\mathrm{L}^{*}$ was obtained for BGS (80.09) and the weakest for GF (23.10) respectively. The coordinate $\mathrm{a}^{*}$ translated the green (a-) and red $(\mathrm{a}+)$ colors in the chromatic space. All the values obtained for this parameter were slightly positive. The low values and was observed with the BGV (-0.98) and BGF (0.2) respectively. These values reflect the white color of this variety. The two other colored varieties ( $\mathrm{G}$ and $\mathrm{VG}$ ) presented the greatest values, thus colors which tend to be red. Solar or electric dehydration involved a significant growth of $\mathrm{a}^{*}$, so the powders were more colored (red color) than the respective fresh samples. Electric dehydration provided a varied ranks values of $a^{*}$. This could be explained by the fact that electric dehydration was softer because of a better control of the temperature. Values of $b^{*}$ parameter obtained for the fresh samples were positive ( 3.11 for the VGF; 4.56 for the BGF and $5.62 \mathrm{GF})$. The results showed that the dehydration type had no significant influence on the values of $b^{*}$ for the varieties VG and G. Meanwhile, the BG had a slight increase of browning during dehydration certainly due to Maillard's reactions. These non-enzymatic reactions generally appear during heat food treatment and they depend mainly on temperature and processing time [24]. Nevertheless, ash contents varied from $3.33 \mathrm{~g} / 100 \mathrm{~g}$ (VGS and BGV) to $4.94 \mathrm{~g} / 100 \mathrm{~g}$ DM (BGF). These results correlated well with other studies more or less for different varieties of onions [25]. In the same table, vitamin C contents varied from $3.26 \mathrm{mg} / 100 \mathrm{~g} \mathrm{DM}$ (BGS) to $45.07 \mathrm{mg} / 100$ $\mathrm{g}$ FM (VGF). A significant $(\mathrm{p}<0.05)$ reduction of vitamin $\mathrm{C}$ was observed as a function of dehydration types which was at least $72 \%$. Vitamin C losses may be due to several factors i.e. photooxidative and/or thermo sensitive reactions [26]. These authors suggested the use of additives such as $\mathrm{SO}_{2}$ or $\mathrm{CaCl}_{2}$ that could protect vitamin $\mathrm{C}$. In addition, lipid contents of the onion bulbs varieties was significantly $(\mathrm{p}<0.05)$ influenced by the type of treatment. These values oscillated between $2.06 \mathrm{~g} / 100 \mathrm{~g}$ DM for BGS and $4.31 \mathrm{~g} / 100 \mathrm{~g} \mathrm{DM}$ VGF that was the highest value observed for fresh samples. Lipid oxidation could explain the slight decrease of lipid content noticed during dehydration. Favier et al. obtained almost similar results on vegetables with contents varying from 1 to $3 \mathrm{~g} / 100 \mathrm{~g}$ DM [27]. On the other hand, Nwinuka et al. observed lower values on onion powders $(0.95 \mathrm{~g} / 100 \mathrm{~g} \mathrm{DM})$ in Nigeria [28]. This difference could be due to the dehydration type but mainly the varieties of onions bulbs. Also, protein content varied overall between $9.84 \mathrm{~g} / 100$ g DM (BGF) to $13.4 \mathrm{~g} / 100 \mathrm{~g} \mathrm{DM}(\mathrm{VGV})$. These values fairly

Table 1. Proximate physico-chemical composition of some onion bulb varieties.

\begin{tabular}{|c|c|c|c|c|c|c|c|c|c|c|}
\hline Samples & $\begin{array}{l}\text { Moisture } \\
(\mathrm{g} / 100 \mathrm{~g})\end{array}$ & $\mathrm{pH}$ & $\begin{array}{c}\text { Ash } \\
(\mathrm{g} / 100 \mathrm{~g})\end{array}$ & $\begin{array}{c}\text { Available } \\
\text { sugar }(\mathrm{g} / 100 \mathrm{~g})\end{array}$ & $\begin{array}{l}\text { Proteins } \\
(\mathrm{g} / 100 \mathrm{~g})\end{array}$ & $\begin{array}{l}\text { Lipids } \\
\text { (g/100 g) }\end{array}$ & $\begin{array}{l}\text { Vitamin C } \\
(\mathrm{g} / 100 \mathrm{~g})\end{array}$ & $L^{*}$ & $a^{*}$ & $\mathbf{b}^{*}$ \\
\hline BGF & $88.65 \pm 0.35 f$ & $6.24 \pm 0.05 a$ & $4.94 \pm 0.02 e$ & $55.92 \pm 0.01 a$ & $9.84 \pm 0.06 a$ & $3.77 \pm 0.01 \mathrm{e}$ & $38.11 \pm 1.36 c$ & $29.59 \pm 1.64 b$ & - & $4.56 \pm 0.26 a b$ \\
\hline BGS & $8.30 \pm 0.09 d$ & $6.61 \pm 0.01 c$ & $3.41 \pm 0.01 b$ & $25.37 \pm 0.24 e$ & $10.99 \pm 0.10 b$ & $2.06 \pm 0.05 a$ & $3.26 \pm 0.01 a$ & $80.09 \pm 0.68 f$ & $0.66 \pm 0.01 b c$ & $17.87 \pm 0.29 e$ \\
\hline BGV & $7.94 \pm 0.06 c$ & $6.70 \pm 0.01 d$ & $3.33 \pm 0.01 a$ & $23.54 \pm 0.15 c$ & $11.31 \pm 0.06 c$ & $3.62 \pm 0.01 d$ & $4.87 \pm 2.29 a$ & $71.68 \pm 0.19 e$ & $-0.98 \pm 0.02 a$ & $11.54 \pm 0.38 d$ \\
\hline GF & $87.65 \pm 0.35 \mathrm{e}$ & $6.38 \pm 0.01 b$ & $4.54 \pm 0.07 c$ & $56.28 \pm 0.32 f$ & $11.15 \pm 0.08 b c$ & $3.53 \pm 0.04 \mathrm{~cd}$ & $29.22 \pm 1.77 b c$ & $24.35 \pm 1.52 a$ & $0.29 \pm 0.07 b$ & $5.62 \pm 0.43 b$ \\
\hline GS & $7.68 \pm 0.04 b$ & $6.78 \pm 0.01 \mathrm{e}$ & $3.35 \pm 0.01 a$ & $23.55 \pm 0.39 c$ & $12.03 \pm 0.15 d$ & $3.44 \pm 0.03 b c$ & $6.22 \pm 0.01 a$ & $71.75 \pm 0.34 \mathrm{e}$ & $2.46 \pm 0.05 d$ & $9.23 \pm 0.60 c$ \\
\hline GV & $8.09 \pm 0.01 c$ & $6.66 \pm 0.02 \mathrm{~cd}$ & $3.38 \pm 0.01 \mathrm{ab}$ & $24.39 \pm 0.36 d$ & $12.43 \pm 0.08 e$ & $3.38 \pm 0.04 b$ & $10.07 \pm 0.01 a$ & $61.32 \pm 1.23 d$ & $5.47 \pm 0.02 e$ & $8.64 \pm 0.17 c$ \\
\hline VGF & $88.00 \pm 0.01 \mathrm{e}$ & $6.36 \pm 0.03 b$ & $4.70 \pm 0.02 d$ & $61.56 \pm 0.41 \mathrm{~g}$ & $12.09 \pm 0.03 d$ & $4.31 \pm 0.03 g$ & $45.07 \pm 0.01 c$ & $23.10 \pm 1.16 a$ & $1.39 \pm 0.37 c$ & $3.11 \pm 0.07 a$ \\
\hline VGS & $9.01 \pm 0.01 a$ & $6.65 \pm 0.01 \mathrm{~cd}$ & $3.33 \pm 0.01 a$ & $21.34 \pm 0.15 b$ & $12.53 \pm 0.03 e$ & $4.06 \pm 0.15 f$ & $12.39 \pm 0.01 \mathrm{ab}$ & $78.18 \pm 0.12 f$ & $4.69 \pm 0.31 e$ & $3.13 \pm 0.04 a$ \\
\hline VGV & $8.99 \pm 0.02 a$ & $6.70 \pm 0.02 d$ & $3.38 \pm 0.01 \mathrm{ab}$ & $25.44 \pm 0.18 e$ & $13.4 \pm 0.06 f$ & $3.77 \pm 0.04 \mathrm{e}$ & $14.55 \pm 2.28 \mathrm{ab}$ & $57.87 \pm 0.24 c$ & $7.47 \pm 1.10 f$ & $4.38 \pm 1.76 a b$ \\
\hline
\end{tabular}

${ }^{*} \mathrm{~N}=3$; means $\pm \mathrm{sd}$; values with different letters within a column are significantly different at $5 \%$ level. BGF: White of galmi fresh, BGS: White of galmi solar dehydration, BGV: White of galmi electrical dehydration, GF: Goudami fresh, GS: Goudami solar dehydration, GV: Goudami electrical dehydration, VGF: Violet of galmi fresh, VGS Violet of galmi solar dehydration, VGV: Violet of galmi electrical dehydration. 
coincide with those obtained by Abhayawick et al. which range between 6 to $15 \mathrm{~g} / 100 \mathrm{~g}$ DM, respectively for the cultivars Spirit and Sweet vidalia. Additionally, Table 1 showed a significant difference $(p<0.05)$ between BGF, BGS, BGV, GF, and GV but not for the others VGF, VGS, VGV and GS. The increase of protein contents was due to the effect of concentration related to dehydration. According to USDA (2000), the recommended daily allowance must bring 50 to $63 \mathrm{~g}$ proteins per day [29]. Still, $80 \%$ of proteins are from vegetable origin in developing countries. Furthermore, consumption of vegetable proteins is more economic and accessible for people rather than animal proteins. For this reason, onion varieties could contribute in a considerable way to human protein needs. In the same way, the level of available sugar of onion varieties varied $(p<0.05)$ according to the mode of drying. It came out in Table 1 that these bulbs were rich in available sugars and varied between 21.34 g/100 g DM (VGS) to 61.56 g/100 g DM (VGF). Moreover, results showed that the untreated varieties presented a higher sugar contents than dried varieties. This very pronounced decrease of sugar content could be due to non-enzymatic browning which imply reactions between free amino groups of proteins and reducing sugars that gave a brown color [30].

\section{Determination of minerals}

Minerals results are summarize in Table 2. The highest Calcium (Ca) values $(764.95 \mathrm{mg} / 100 \mathrm{~g} \mathrm{DM})$ were obtained for VGS whereas the lowest $(300.6 \mathrm{mg} / 100 \mathrm{~g} \mathrm{DM})$ was obtained for GV. This high percentage of Ca varied significantly $(\mathrm{p}<0.05)$ in function of the studied onion varieties. Values of the onion bulbs could contribute to the recommended daily allowance of $\mathrm{Ca}$ that varies from 800 to $1200 \mathrm{mg}$ per day [29], where the quantity of magnesium $(\mathrm{Mg})$ was between $44.82 \mathrm{mg} / 100$ $\mathrm{g}$ DM for BGS and $60.39 \mathrm{mg} / 100 \mathrm{~g} \mathrm{DM}$ for GS. Our data showed that the dehydration type did not influence the content of this mineral except for BG. Daily needs for human of $\mathrm{Mg}$ are approximately between 0.35 and $0.4 \mathrm{~g}$ [31]. The onions bulbs can thus contribute as a complement to satisfy daily $\mathrm{Mg}$ requirements. Nevertheless, zinc ( $\mathrm{Zn}$ ) contents for GS and VGV ranged between $1.47 \mathrm{mg} / 100 \mathrm{~g}$ DM to $15.56 \mathrm{mg} / 100 \mathrm{~g}$ DM. The dehydration type and variety influenced significantly $(\mathrm{p}<0.05)$ the values. Similarly, sodium $(\mathrm{Na})$ level in the onion bulbs varied significantly $(\mathrm{p}<0.05)$ and ranged between $25.29 \mathrm{mg} / 100 \mathrm{~g}$ DM (GS) and $49.64 \mathrm{mg} / 100 \mathrm{~g} \mathrm{DM}$ (VGV). The dehydration type had a significant influence $(\mathrm{p}<0.05)$ for sodium content except for BG. These values were higher than those of leaves of Colocasia esculenta L (7.0 mg/100 g DM) reported by Ejoh et al. [32].

In addition, our results showed that the type of dehydration had non-significant effect $(\mathrm{p}<0.05)$ on the potassium $(\mathrm{K})$ content for VG variety. The values obtained were $206.83 \mathrm{mg} / 100 \mathrm{~g}$
DM (BGV) and $266.5 \mathrm{mg} / 100 \mathrm{~g} \mathrm{DM}(\mathrm{VGS})$. The high level of $\mathrm{K}$ compared with $\mathrm{Na}$ in our treatments is important for its effectiveness on the fall of the blood pressure [33]. Although, $\mathrm{K}$ in spite of its considerable content in onions was not enough to satisfy to daily needs for human which ranges between 2 to $6 \mathrm{~g}$. Furthermore, the content of iron $(\mathrm{Fe})$ was influenced significantly by the dehydration type $(\mathrm{p}<0.05)$ except for the VG. The values ranged between $2.57 \mathrm{mg} / 100 \mathrm{~g} \mathrm{DM}$ (BGS) and $8.34 \mathrm{mg} / 100 \mathrm{~g} \mathrm{DM}$ (GS). Values were lower than those observed on Haricot bean (30.6 mg/100 g DM) by Sanglonis and Machado. The daily requirements of Fe are estimated between 10 and $15 \mathrm{mg}$. So, the onion powder has a sufficient content to satisfy food requirements of $\mathrm{Fe}$ especially for the African countries that remain most vulnerable vis-a-vis the $\mathrm{Fe}$ deficiency caused by malaria.

Finally, the phosphorus $(\mathrm{P})$ content was significantly $(\mathrm{p}<0.05)$ influenced by the dehydration except for the BGV and VGS varieties. These P content varied between $23.40 \mathrm{mg} / 100 \mathrm{~g} \mathrm{DM}$ (VGV) with $343.24 \mathrm{mg} / 100 \mathrm{~g} \mathrm{DM}$ for BGS. Although onion powders were rich in $\mathrm{P}$ and could contribute slightly to the human daily needs of this mineral, however the quantity of $\mathrm{P}$ required varies from 800 to $1200 \mathrm{mg}$ [34].

\section{Principal component analysis (PCA)}

Consecutively, all variable detailed in Table 1 were analyzed via principal component analysis (PCA). The two principal components ( $\mathrm{PC} 1=\mathrm{F} 1$ and $\mathrm{PC} 2=\mathrm{F} 2$ ) proved to be interesting for analysis. Figure 1 represents the circle of correlation of the variables on the axe plan F1 and F2. Data explained about $91.70 \%$ of the expressed results. In this circle, we note that the moisture, vitamin $\mathrm{C}$, ash and available sugars were strongly correlated in a positive way with $\mathrm{F} 1$. On the other hand, $\mathrm{pH}$, $\mathrm{L}^{*}$ were negatively correlated. F1 only explained $56.10 \%$ of the results. The proteins, lipids, $\mathrm{a}^{*}$ values were much correlated positively with $\mathrm{F} 2$, whereas the variable $\mathrm{b}^{*}$ was negatively on the same axis which explains $25.60 \%$.

In the same manner, the Figure 2 illustrates the cartography of the onion bulbs analyzed on the axe plan F1 x F2 with 91.70 $\%$. Also, Figure 2 could regroup the varieties in three principal classes with $91.70 \%$ : class 1 which regroups VGF, BGF and GF; class 2 made up of BGV, BGS and GS and class 3 which regroups $\mathrm{GV}, \mathrm{VGV}$ and VGS. Classes 1 corresponded in this analysis to the groups of the varieties which showed a strong positive contribution with F1. Consequently, a correlation was with the moisture, ash, available sugars, vitamin $C$, ash, and $\mathrm{L}^{*}$. The other classes included the varieties with a strong positive contribution with F2. Thus had a similar composition to proteins, lipids, $\mathrm{L}^{*}, \mathrm{a}^{*}$ and $\mathrm{b}^{*}$.

Table 2. Mineral composition of three bulb onion varieties.

\begin{tabular}{|c|c|c|c|c|c|c|c|}
\hline Treatment & $\mathrm{Na}(\mathrm{mg} / 100 \mathrm{~g} \mathrm{DM})$ & $\mathrm{K}$ (mg/100 g DM) & $M g(m g / 100 \mathrm{~g} \mathrm{DM})$ & Zn (mg/100 g DM) & $\mathrm{Fe}(\mathrm{mg} / 100 \mathrm{~g} \mathrm{DM})$ & $P$ (mg/100 g DM) & $\mathrm{Ca}(\mathrm{mg} / 100 \mathrm{~g} \mathrm{DM})$ \\
\hline BGS & $30.87 \pm 2.56 b$ & $253.48 \pm 8.91 b$ & $45.36 \pm 1.25 a$ & $6.04 \pm 0.01 b$ & $2.57 \pm 1.21 \mathrm{a}$ & $343.24 \pm 4.66 \mathrm{e}$ & $705.44 \pm 10.28 d$ \\
\hline BGV & $28.11 \pm 0.84 a b$ & $206.83 \pm 17.62 a$ & $44.82 \pm 1.24 a$ & $8.46 \pm 0.70 c$ & $5.08 \pm 0.01 b$ & $321.21 \pm 11.52 d$ & $653.89 \pm 10.16 c$ \\
\hline GS & $25.29 \pm 0.83 a$ & $223.04 \pm 3.46 a$ & $54.49 \pm 1.22 b$ & $1.47 \pm 0.69 a$ & $8.34 \pm 1.18 c$ & $300.12 \pm 8.80 c$ & $523.39 \pm 20.00 b$ \\
\hline GV & $29.16 \pm 0.84 b$ & $254.21 \pm 5.26 b$ & $60.39 \pm 1.23 c$ & $4.96 \pm 0.01 b$ & $4.22 \pm 1.19 a b$ & $252.05 \pm 3.67 b$ & $300.6 \pm 20.24 a$ \\
\hline VGS & $37.38 \pm 1.65 c$ & $266.5 \pm 1.72 b$ & $57.5 \pm 3.64 b c$ & $10.21 \pm 0.68 c$ & $4.96 \pm 0.01 b$ & $240.77 \pm 5.40 a b$ & $764.95 \pm 29.77 e$ \\
\hline VGV & $49.64 \pm 0.82 d$ & $261.63 \pm 5.16 b$ & $54.93 \pm 0.01 b$ & $15.56 \pm 1.37 d$ & $4.14 \pm 1.17 a b$ & $234.40 \pm 3.60 a$ & $519.32 \pm 19.84 b$ \\
\hline
\end{tabular}




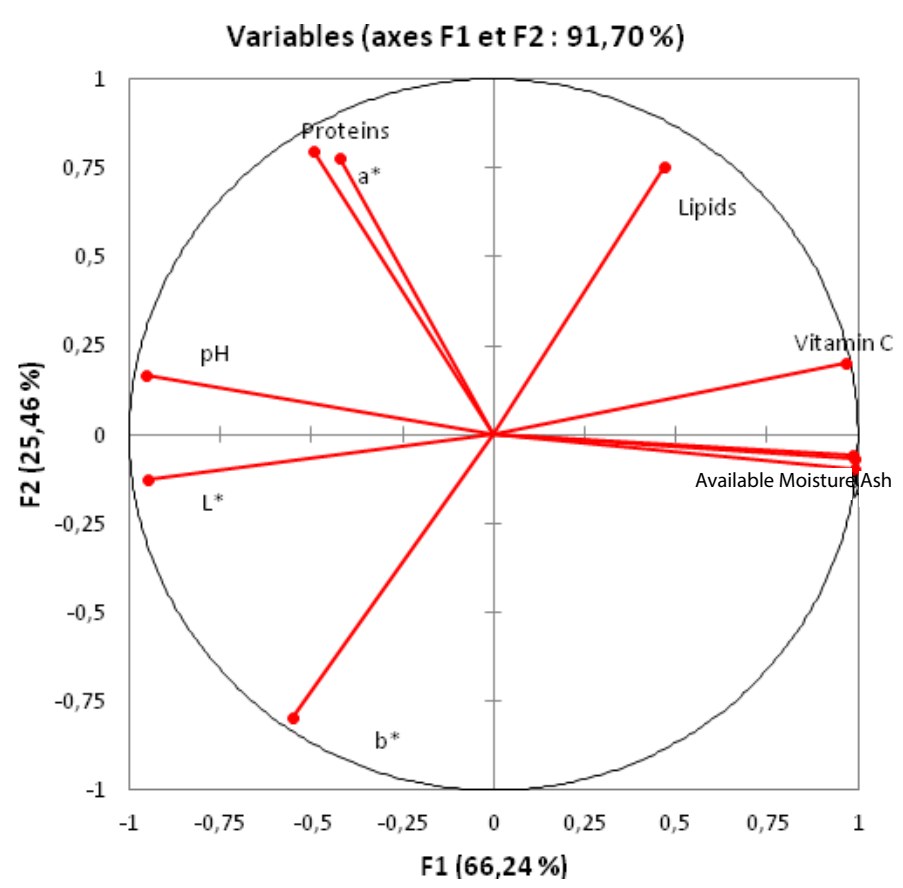

Figure 1. Two dimensional plots of onion bulb coordinates on varimax rotated $F 1 x F 2$ axes.

Observations (axes F1 et F2: 91,70\%)

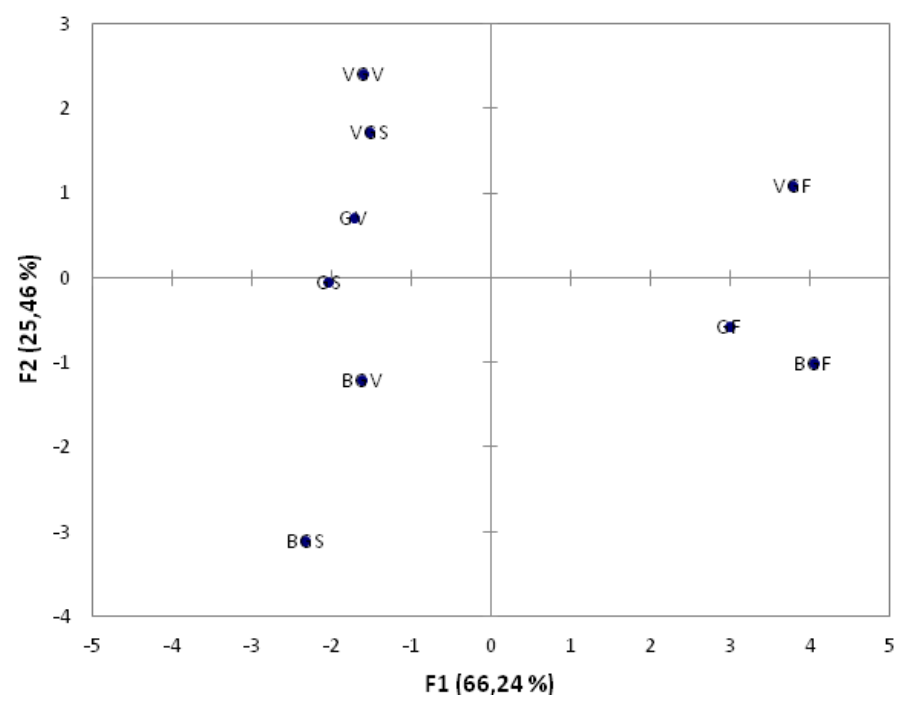

Figure 2. Two dimensional plots of onion bulb coordinates on varimax rotated F1xF2 axes refer to Table 1 for abbreviation of onion.
In addition, Table 3 indicated the correlation of Pearson which permits to better appreciate the relation between the analyzed variables in Table 1. It comes out that the given physiochemical variables were strongly inter-correlated. A strong positive correlation was also observed between available sugar-moisture $(\mathrm{r}=0,993, \mathrm{p}<0.05)$; available sugar and ash $(\mathrm{r}=0.982, \mathrm{p}<0.05)$; ash-moisture $(\mathrm{r}=0.989, \mathrm{p}<0.05)$; ash-vitamin $\mathrm{C} \quad(\mathrm{r}=0.944$, $\mathrm{p}<0.05)$ and vitamin $\mathrm{C}$-moisture $(\mathrm{r}=0.941, \mathrm{p}<0.05)$. These values were explained by the fact that vitamin $\mathrm{C}$ and available sugar are water-soluble. Moreover, the Pearson correlation matrix showed a significant negative correlation $(\mathrm{r}=-0.951$, $\mathrm{p}<0.05$ ) between moisture and $\mathrm{L}^{*}$. However, dehydration caused a bleaching (significant growth of $\mathrm{L}^{*}$ ) of the fruits and vegetables [34]. A negative correlation was also noted between the vitamin $\mathrm{C}$ with $\mathrm{L}^{*}(\mathrm{r}=-0.935, \mathrm{p}<0.05) ; \mathrm{b}^{*}(\mathrm{r}=-0.668, \mathrm{p}<0.05)$ of the color, $\mathrm{pH}$ and available sugar $(\mathrm{r}=-0,936, \mathrm{p}<0.05)$. This could be explained by the strong hydro-solubility of vitamin $\mathrm{C}$ and the negative correlation between the moisture with $\mathrm{L}^{*}$ and $\mathrm{b}^{*}$ of the color.

Concerning minerals, the principal component of $\mathrm{F} 1$ had a contribution of $60.49 \%$ and $24.03 \%$ for F2 (Figure 3). Ca, Na, $\mathrm{K}, \mathrm{Zn}$ and $\mathrm{P}$ were positively correlated with axe F1. Meanwhile the minerals $\mathrm{Mg}$ and Fe were positively correlated with axe F2.

\section{Fourier transformed infra-red spectroscopy}

Fourier transformed Infra-red spectroscopy (FT-IR) was used to evaluate structural differences between the onion bulbs according to dehydration types. The obtained spectra presented a similar shape for all powder samples independent of dehydration types. The only observed difference was on the intensity level of certain principal peaks. The spectral features of three varieties of onion powders according to dehydration types are shown in Figure 4. The bands between the wave numbers of 750$1800 \mathrm{~cm}^{-1}$ (finger print regions) represented the biochemical compositions, especially the moieties of carbohydrate, lipid, protein secondary structures (a-helix, b-sheet and random coil), and polyphenols in plants. The peak with the wave number $1740 \mathrm{~cm}^{-1}$ illustrated the vibration characteristic of the acidic group $\mathrm{CO}$ stretch. The distinctive peak at the wave number of $1614 \mathrm{~cm}^{-1}$ was assigned to liaison CAC stretch of phenyl which is present at high levels in the poly phenolic components in onions. The band at $1416 \mathrm{~cm}^{-1}$ observed could be due to $\mathrm{CH}_{3}$ asymmetric deformation. Also, the peak at $1366 \mathrm{~cm}^{-1}$ obtained

Table 3. Correlation between the analyzed physico-chemical characteristics.

\begin{tabular}{|c|c|c|c|c|c|c|c|c|c|c|}
\hline Variables & Moisture & $\mathrm{pH}$ & Ash & A sugar & Proteins & Lipids & Vit C & $L^{*}$ & $\mathbf{a}^{*}$ & $\mathbf{b}^{*}$ \\
\hline Moisture & 1 & - & - & - & - & - & - & - & - & - \\
\hline $\mathrm{pH}$ & -0.951 & 1 & - & - & - & - & - & - & - & - \\
\hline Ash & 0.989 & -0.97 & 1 & - & - & - & - & - & - & - \\
\hline A sugar & 0.993 & -0.936 & 0.982 & 1 & - & - & - & - & - & - \\
\hline Proteins & -0.518 & 0.624 & -0.569 & -0.476 & 1 & - & - & - & - & - \\
\hline Lipids & 0.384 & -0.261 & 0.36 & 0.369 & 0.296 & 1 & - & - & - & - \\
\hline Vit C & 0.941 & -0.899 & 0.944 & 0.948 & -0.292 & 0.575 & 1 & - & - & - \\
\hline$L^{*}$ & -0.951 & 0.864 & -0.933 & -0.958 & 0.314 & -0.472 & -0.935 & 1 & - & - \\
\hline$a^{*}$ & -0.462 & 0.457 & -0.46 & -0.449 & 0.845 & 0.201 & -0.229 & 0.264 & 1 & - \\
\hline$b^{*}$ & -0.49 & 0.398 & -0.468 & -0.462 & -0.288 & -0.913 & -0.668 & 0.579 & -0.353 & 1 \\
\hline
\end{tabular}




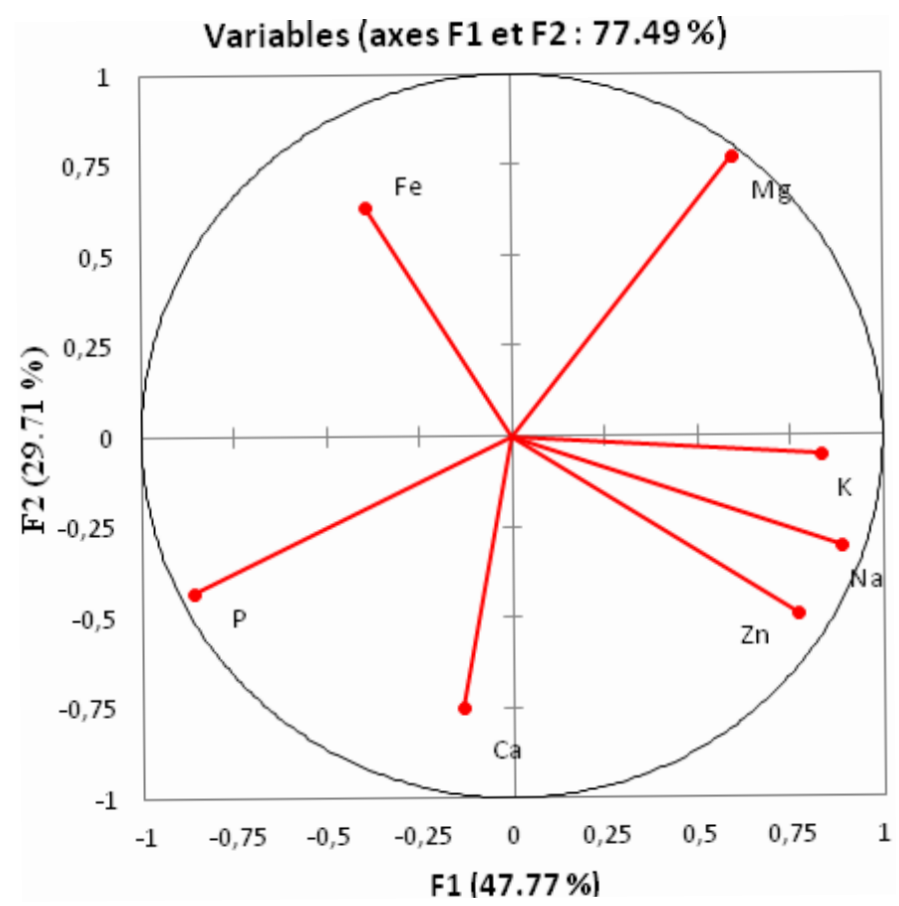

Figure 3. Two dimensional plots of onion bulb coordinates on varimax rotated F1xF2 axes.

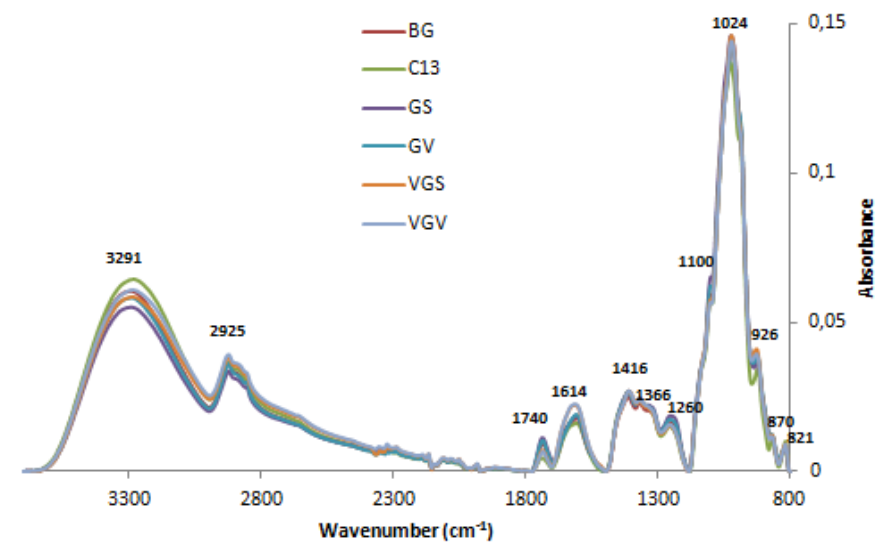

Figure 4. Representative FT-IR raw spectra of onion according to the type of drying. BS: White of galmi solar drying. C13: White of galmi electrical drying. GS: Goudami solar drying. GV: Goudami electrical drying. VGV: Violet of galmi electrical drying. VGS: Violet of galmi solar drying.

could be due to the in-plane CAO stretching vibration combined with the liaison stretch of phenyl. The minor band at 1260 $\mathrm{cm}^{-1}$ was from amide III (random coil) for protein. The wave number region from 950 to $1200 \mathrm{~cm}^{-1}$ contained functional groups mainly from carbohydrate. The "shoulder" peak that appear at $1100 \mathrm{~cm}^{-1}$ was a carbohydrate while the bands at $1024 \mathrm{~cm}^{-1}$ could be due to vibrational frequency of $\mathrm{ACH}_{2} \mathrm{OH}$ groups of carbohydrates. The bands at both 870 and $926 \mathrm{~cm}^{-1}$ were assigned to the left-handed helix DNA ( $Z$ form). The band at $821 \mathrm{~cm}^{-1}$ was caused by $\mathrm{CH}$ bond deformation, which could also reflect structural information about polyphenols [7]. For the higher wave numbers (lower frequencies), the peak at $3291 \mathrm{~cm}^{-1}$ was due to NAH stretching of proteins and OAH stretching of carbohydrates and moisture while the peak at $2925 \mathrm{~cm}^{-1}$ was due to $\mathrm{CH}_{2}$ anti-symmetric stretch for methyl groups mainly for lipids [35] and it presented at $2851 \mathrm{~cm}^{-1}$ reflected to $\mathrm{CH}$ stretch of methylene groups.

\section{Scanning electron microscopy (SEM)}

The microscopic observation of Figure 5 permits to bring out the microstructural distinction between the onion powders according to their drying methods. Indeed, an uneven and honeycombed surface structure was observed to onion powder dried in the sun (Figure 5a, 5c and 5e), while for onion powders dried by electrical ventilation surface is coated regularly multiple identical flake (Figure 5b, 5d and 5f) probably referring to crystalline sugar [36].These observations confirm the results obtained by infrared which showed that carbohydrates are the major constituents of the studied onion powder.

\section{Conclusion}

This work aimed to evaluate the effect of dehydration on the physicochemical parameters of three varieties of onion bulbs. Results of the analyzed variables showed that the irrespective of the type of dehydration used there were significant effects on the physicochemical characteristics of onion bulbs. It thus noted a significant loss in vitamin $\mathrm{C}$ (from 72-91\%) according to the mode of dehydration. It was also noticed a reduction in the available sugar contents. The parameters of the color generally increased during dehydration. The treatments also involved an increase of the protein contents. For the onions
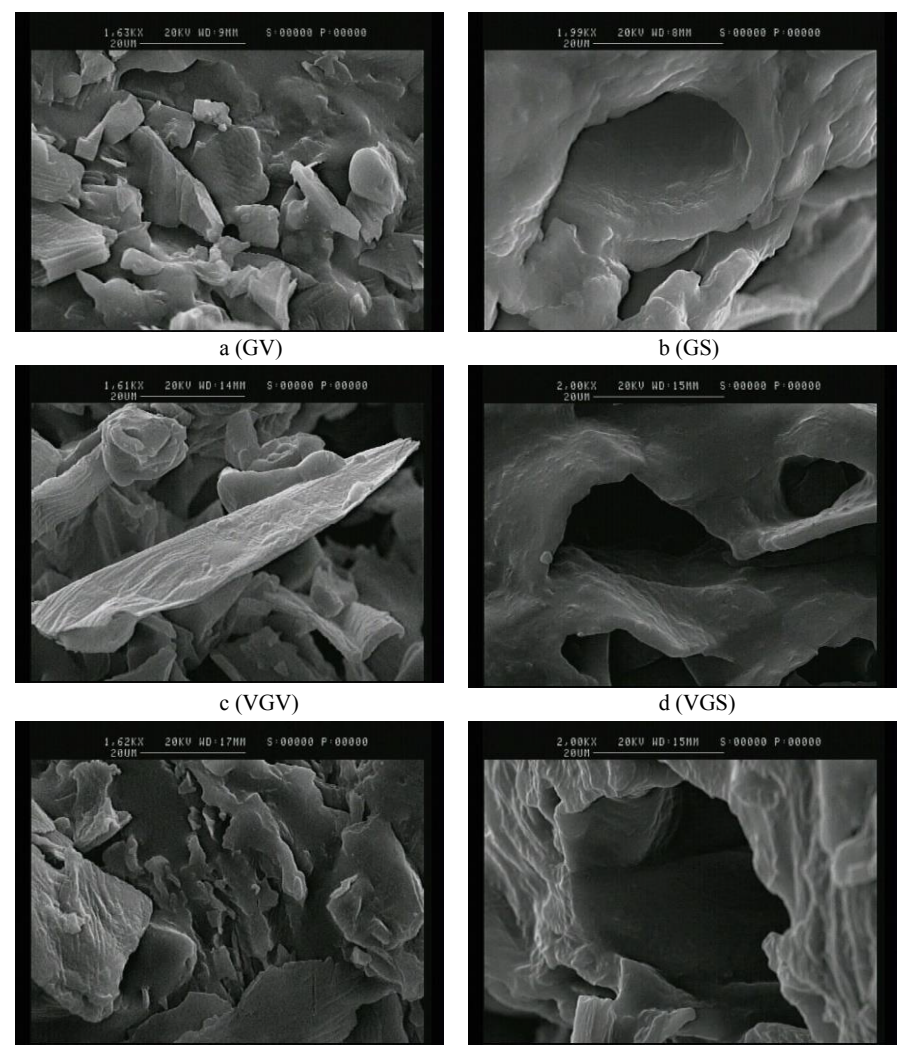

e (BGV)

$\mathrm{f}(\mathrm{BGS})$

Figure 5. Scanning electron microscopy of onion according to the type of drying. a), c), e): x 1620; b), d), f): $x$ 2000. BS: White of galmi solar drying. BV: White of galmi electrical drying. GS: Goudami solar drying. GV: Goudami electrical drying. $V G V$ : Violet of galmi electrical drying. VGS: Violet of galmi solar drying. 
Citation: Armand AB, Scher J, Aboubakar, et al. Effect of three drying methods on the physicochemical composition of three varieties of onion (Allium cepa L). J Food Sci Nutr. 2018;1(2):17-24.

powdered carbohydrate was found to be the major constituent. Moisture was the principal constituent of fresh onion bulbs. All the varieties presented a $\mathrm{pH}$ slightly acidic. The results of this study could be used as reference mark for the choice to develop an adapted method of dehydration of these onion bulbs subject to additional studies.

\section{Acknowledgements}

This research was supported by the French-Cooperation with government of Cameroon.

\section{References}

1. Parfitt J, Barthel M, Macnaughton S. Food waste within food supply chains: quantification and potential for change to 2050. Phil Trans R Soc. 2010;365:3065-81.

2. Mota CL, Luciano C, Dias A, et al. Convective drying of onion: Kinetics and nutritional evaluation. Food bio process. 2011;88:115-23.

3. Sun-Waterhouse D, Bronwen G, Smith Charmian J, et al. Effect of raw and cooked onion dietary fibre on the antioxidant activity of ascorbic acid and quercetin. Food Chem 2008;111:580-5.

4. Food and Agricultural Organization (FAO). Area and production data. 2009.

5. Hamauzu Y, Nosaka T, Ito F, et al. Physicochemical characteristics of rapidly dried onion powder and its antiatherogenic effect on rats fed high-fat diet. Food Chem 2011;129:810-5.

6. Abdou Bouba A, Toua V, Nkouam Gilles B, et al. Effect of solar and electric drying on the content of the phenolic compounds and antioxidant activity of three varieties of onion (Allium cepa L). Int J Biol, Pharm All Sci. 2012;1:204-20

7. Xiaonan Lu, Wang J, Al-Qadiri HM, et al. Determination of total phenolic content and antioxidant capacity of onion (Allium cepa) and shallot (Allium oschaninii) using infrared spectroscopy. Food Chem 2011;129:637-44.

8. Temple L. Quantification des productions et des échanges de fruits et légumes au Cameroun. Cahiers Agricultures 2001;10:87-94.

9. Cathala M, Woin N, Essang T. Onion, a booming production in North Cameroon. Proceedings of the colloquium, Garoua, Cameroon. Prasac, N'Djamena, Chad - Cirad, Montpellier, France. 2002.

10. Arslan D, Ozcan MM. Study the effect of sun, oven and microwave drying on quality of onion slices. LWT - Food Sci Tech. 2010;43:1121-7.

11. Pinela J, Barros L, Carvalho AM, et al. Influence of the drying method in the antioxidant potential and chemical composition of four shrubby flowering plants from the tribe Genisteae (Fabaceae). Food Chem Toxicol. 2011;49:2983-9.

12. Raquel PF, Guinea, Barroca MB. Effect of drying treatments on texture and color of vegetables (pumpkin and green pepper). Food bio proces. 2012;90:58-63.

13. AOAC. Official Methods of Analysis (Vol. 2, 15th ed). Washington, DC: Association of Official Analytical Chemists 1990.

14. Njintang YN, Mbofung CMF, Balaam F, et al. Effect of taro (Colocasia esculenta) flour addition on the functional and alveographic properties of wheat flour and dough, J Sci Food Agri. 2007;88:273-9.

15. Folch J, Lees M, Sloane GSH. A simple method for the isolation and purification of total lipids from animal tissue. J Biol Chem. 1957;226:497-509.

16. Raghu V, Kalpana P, Srinivasan K. Comparison of ascorbic acid content of Emblica officinalis fruits determined by different analytical methods. J Food Compos Anal. 2007;20:529-33.

17. Skunjins S. Handbook for ICP-AES (Varian-Vista), A short guide to Vista Series ICP-AES operation. Version 1.0. Varian Int AG Zug 1998.

18. AACC. Approved Methods of the American Association of Cereal Chemists. The Association, St. Paul N. 1995;40-71.

19. CIE. Official recommendations on uniform colour spaces colour differences equations and metric colour terms. Supplement $\mathrm{N}^{\mathrm{o}} 2$ to CIE publication, $\mathrm{N}^{\circ} 15$, Paris, France. 1976.

20. Statgraphics. Statgraphics plus for windows 3.0.Rockville. MD: Manugistics Inc. 1997.

21. XLSTAT. COPYRIGHT (c) 2007. Addinsoft SARL, Paris, France tous droits réservés. XLSTAT(r) est une marque déposée de Addinsoft Sarl. Paris, France, November 2007.

22. Ekholm P, Reinivuo H, Mattila P, et al. Changes in the mineral and trace element contents of cereals, fruits and vegetables in Finland. J Food Compos Anal. 2007;20:487-95.

23. Abhayawick L, Laguerre JC, Tauzin V, et al. Physical properties of three onion varieties as affected by the moisture content. J Food Eng. 2002;55:253-62.

24. Chua KJ, Mujumdar AS, Hawlader MNA, et al. Batch drying of banana pieces - effect of stepwise change in drying air temperature on drying kinetics and product colour. Food Res Intl. 2001;34:721-31.

25. Nwinuka IM, Ibeh GO, Ekeke GI. Proximate composition and levels of some toxicants in four commonly consumed spices. J Appl Sci Environ Mgt. 2005;9:150-5.

26. Vega-Galvez A, Lemus-Mondaca R, Bilbao-Sainz C, et al. Effect of air drying temperature on the quality of rehydrated dried red bell pepper (var Lamuyo). J Food Eng. 2008;85:42-50.

27. Favier JC, Ireland-Ripert J, Toque C, et al. General Food Directory, 2nd Edition. Inra, Cneva, Tec and Doc Lavoisier, Paris. 1996.

28. Nwinuka IM, Ibeh GO, Ekeke GI. Proximate composition 
Citation: Armand AB, Scher J, Aboubakar, et al. Effect of three drying methods on the physicochemical composition of three varieties of onion (Allium cepa L). J Food Sci Nutr. 2018; 1(2):17-24.

and levels of some toxicants in four commonly consumed spices. J Appl Sci Environ Mgt. 2005;9:150-5.

29. USDA. United States Department of Agriculture. Nutritional Dietary (RDA) Recommanded Dietary Allowance. IFA publ. 2000.

30. Machiels D, Istasse L. The Maillard reaction: importance and applications in food chemistry. Ann Med Vet 146:347-52.

31. Nestel P, Briend A, De Benoist B, et al. Complementary Food Supplements to Achieve Micronutrient Adequacy for Infants and Young Children. J Pediatr Gastroenterol Nutr. 2003;36:316-28.

32. Ejoh AR, Mbiapo FT, Fokou E. Nutrient composition of the leaves and flowers of Colocasia esculenta and the fruits of Solanum melongena. Plant Foods Hum Nutr. 1996;49:107-12.

33. Osborne CG, Mc Tyre RB, Dudek J, et al. Evidence for the relationship of calcium to blood pressure. Nutr. Rev. 1996;54:365-81.

34. Ebubekir A, Erkol M. The effect of moisture content on colour characteristics of walnuts. Int J Food Eng 2009;5:13.

35. Lu X, Rasco BA. Determination of antioxidant content and antioxidant activity in foods using infrared spectroscopy and chemometrics: A review. Crit Rev Food Sci Nutr. 2012;52:853-75.

36. Singh S, Bothara SB. Manilkara zapota (Linn.) Seeds: A Potential Source of Natural Gum. Hindawi Publishing Corporation ISRN Pharmaceutics. 2014.

\section{*Correspondence to:}

Abdou Bouba Armand

Laboratory of Biomolecule Engineering

University of Lorraine

France

Tel: 00 (237) 965335 88; 00 (237) 77919502

E-mail: abdouarmand@yahoo.fr 